\title{
Effect of Atherogenesis on Membrane Lipid Constituents of Rabbit Erythrocytes
}

\author{
Najma Begum, M.Sc., Ph.D. and Megha Singh, M.Sc., Ph.D.
}

\begin{abstract}
SUMmary
Lipids from erythrocyte membranes of normal and cholesterol fed animals were isolated and the various fractions were analyzed quantitatively. Erythrocyte membrane lipid composition of animals fed with an atherogenic diet for 2 months revealed marked elevations in cholesterol followed by significant alterations in phospholipids, free fatty acids and triglycerides. These findngs were discussed from the point of view of the role of membrane lipids in the maintenance of cell integrity, shape, and homeostasis.
\end{abstract}

\section{Additional Indexing Words:}

Cell integrity Cell shape Permeability

CHANGES in lipid composition and metabolic activity of erythrocyte 1 membranes have been reported in a variety of pathological conditions like spur cell anemia, ${ }^{1)-3 \text { ( }}$ hypothyroidism, ${ }^{4,5)}$ diabetes mellitus, ${ }^{6}$ ) liver diseases, ${ }^{7)-10)}$ lecithin-cholesterol acyl transferase deficiency, ${ }^{11)}$ and Zieve's syndrome. ${ }^{12)}$ In most of the above conditions an altered plasma lipid profile has been attributed to red cell lipid changes.

In atherosclerosis, the biochemical composition of blood is greatly altered. ${ }^{13)-18)}$ This completely changes the environment for the circulating erythrocytes. Very few attempts have been made to study the effect of hypercholesterolemia on the composition of erythrocyte membranes. ${ }^{15}$ In the present study, we aim to analyze the changes in lipid composition of erythrocyte membranes isolated from normal and experimental atherogenic animals with a view to evaluate their role in membrane structure, function and integrity.

From the Biomedical Engineering Division, Indian Institute of Technology, Madras-600 036, India.

Source of Grant: Council of Scientific and Industrial Rescarch (GSIR), India.

Address for reprint: Dr. Najma Begum, Research Officer, Department of Biochemistry, Regional Research Institute of Unani Medicine, 50, West Mada Church Street, Royapuram, Madras-600 013, India.

Received for publication August 29, 1980. 


\section{Materials AND Methods}

White albino rabbits of the same age and sex weighing about $800-1,000 \mathrm{Gm}$ were purchased from King Institute, Guindy and were fed with a normal laboratory diet (Hind Lever Rabbit Feed). A batch of 20 animals were divided into 2 groups of 10 each. Group I served as normal controls. Group II animals were fed with an atherogenic diet (normal diet $+1 \%$ cholesterol). Serum cholesterol levels were monitored every week. Animals with serum cholesterol levels between 1,400-1,600 $\mathrm{mg} \%$ were taken up and their serum cholesterol levels were maintained within the above range by dietary adjustment of cholesterol. At the end of 2 months, blood was drawn from control and experimental animals into heparinized tubes by ear vein puncture. Plasma was separated by centrifugation at $3,000 \mathrm{~g}$ for $10 \mathrm{~min}$. Packed red cells were washed thrice with physiological saline. A known volume of cells with a known hematocrit were used for the isolation of red cell membrane. The method employed was essentially the same as described by Dodge et al. ${ }^{19)}$ The Hb-free red cell ghosts were suspended in minimum quantity of physiological saline. The lipids from the membranes were extracted using chloroform-methanol mixture $(2: 1)$ by the method described by Folch et al. ${ }^{20)}$ The lipids were dried at $37^{\circ} \mathrm{C}$ to constant weight and were redissolved in the above chloroform-methanol mixture. Aliquots of this extract were used for the estimation of cholesterol, $\left.{ }^{21}\right)$ phospholipids, ${ }^{22)}$ free fatty acids, ${ }^{23)}$ and triglycerides. ${ }^{24)}$ Membrane proteins were estimated by the method of Lowry et al. ${ }^{25}$ )

\section{RESULTS}

Table I gives the levels of membrane lipids from erythrocytes of normal and cholesterol fed animals. The total lipid content of erythrocyte membranes from experimental animals was increased by $150 \%$ when compared to normal controls ( $\mathrm{p}<0.005)$.

Analysis of individual lipid components, namely cholesterol, phospholipids, free fatty acids and triglycerides, also revealed marked variations in experimental animal membranes. The levels of cholesterol were found to be

Table I. Effect of Atherogenesis on Lipid Composition of Erythrocyte Membranes Compared ot Normal Controls

\begin{tabular}{l|c|c|c}
\hline \multicolumn{1}{c|}{ Parameter } & Control & Experimental & $\mathrm{p}$ value \\
\hline Total lipids & $243.2 \pm 16.20$ & $600.00 \pm 55.50$ & $<0.005$ \\
Cholesterol (Total) & $143.1 \pm 10.30$ & $425.00 \pm 40.10$ & $<0.005$ \\
Phospholipids & $9.90 \pm 1.25$ & $15.05 \pm 1.50$ & $<0.05$ \\
Free fatty acids & $37.80 \pm 10.50$ & $75.90 \pm 21.30$ & $<0.005$ \\
Triglycerides & $44.60 \pm 11.50$ & $78.40 \pm 16.40$ & 0.05
\end{tabular}

$\mathrm{p}$ is the statistical significance at $5 \%$ level.

Values were the average of 6 individual experiments in duplicate and expressed as $\mathrm{mg} / \mathrm{Gm}$ membrane proteins \pm S.D. Details were given under Materials and Methods. 
elevated by $200 \%$, whilc other lipid components, namely phospholipids, free fatty acids and triglycerides, showed $50 \%, 100 \%$, and $60 \%$ elevations, respectively.

\section{Discussion}

The architecture of red cell membranes is mainly regulated by the composition of lipids and proteins as suggested by Singer and Nicoloson..$^{26)}$ The results presented above show that dietary induced hyperlipidemia is accompanied by concomitant changes in erythrocyte membrane lipids.

The elevations observed in total lipid fractions of erythrocyte membrane may be a mere reflection of dietary induced hyperlipidemia. Thus, Neerhout ${ }^{27)}$ has shown that changes in red cell membrane lipids are acquired in the circulation through interaction with altered plasma lipids. Hence, it is conceivable that the elevations seen in the membrane lipids are due to increased molecular interactions which in turn is due to increase in plasma lipid level in cholesterol-fed animals.

The elevations observed in membrane cholesterol can be explained by the contention that red cell cholesterol is in free equilibrium with unesterified plasma cholesterol, which in turn is regulated by the enzyme lecithin-cholesterol acyl transferase (LCAT) ${ }^{28)}$ Hence, in dietary induced hypercholesterolemia, the acylation capacity of the above enzyme seems to be insufficient when compared to the excess unesterified circulating cholesterol, resulting in elevation of membrane cholesterol and hence an altered membrane surface area, which results in altered red cell shape. ${ }^{29)}$ An alternative explanation is, an abnormality in the usual equilibrium of plasma lipoprotein cholesterol with that of membrane cholesterol. Increased cholesterol content of the membrane along with decreased unsaturation has been observed in aging. ${ }^{30)}$

These changes in membrane lipids are also accompanied by permeability changes and abnormal hematology. ${ }^{311}$ Here, it is interesting to observe that cholesterol regulates the permeability of biological membranes by affecting the internal viscosity. ${ }^{30}$ From these observations, it is tempting to speculate that the change in internal viscosity subsequent to altered membrane lipid composition may be responsible for enhancing the atherogenic process in the aorta along with other factors such as shear rate and turbulant flow. ${ }^{32-34)}$

\section{AGKNOWLEDGMENTS}

The financial help rendered by C.S.I.R. is gratefully acknowledged. The authors are extremely grateful to Dr. T. M. Vatsala, I.I.T., Madras, for her valuable help. 


\section{REFERENCES}

1. Cooper RA, Jandl JH: Bile salts of cholesterol in in the pathogenesis of target cells in obstructive jaundice. J Clin Invest 47: 809, 1968

2. Cooper RA: Spur cells. A red cell defect acquired in serum and modified in the circulation. J Clin Invest 48; 1820, 1969

3. Cooper RA, Kimball DB, Durocher JR: Role of spleen in membrane conditioning and hemolysis of spur cells in liver disease. New Engl J Med 290: 1279, 1974

4. Pasquala E, Perillie, Tembrevilla C: Red cell changes in hypothyroidism. Lancet 2: 1151, 1975

5. Horton L, Caburn RJ, England JM, Heinsworth RL: The hematology of hypothyroidism. Quart J Med (New Series) 65: 101, 1977

6. Gandhi CR, Chowdhury DR: Effect of diabetes mellitus on membrane lipid constituents of human erythrocytes of different ages. Ind J Exptl Biol 16: 818, 1978

7. Smith JA, Lonergon ET, Starling K: Spur cell anemia. Hemolytic anemia with red cells resembling acanthocytes in alcoholic cirrhosis. New Engl J Med 271: 396, 1964

8. Silber R, Amoros E, Lhowe J, Kayden MJ: Spur shaped erythrocytes in Lacnnec's cirrhosis. New Engl J Med 275: 639, 1966

9. Neerhout RG: Erythrocyte lipids in the neonate. Paediat Res 2:172, 1968

10. Powell LW, Halliday JW, Cooksley WGE: Hemolysis in liver disease, relationship to red cell membrane function bilirubin concentration and plasma electrolyte disturbances. Aust New Z J Med 6: 3, 1976

11. Gjore EH, Torsvik K, Norom KR: Scand J Clin Lab Invest 21: 327, 1968

12. Westerman MP, Balcerzak SP, Heinle EW: J Lab Clin Med 72: 831, 1969

13. Khanin AL, Ollshanskii GS, Taberovskaya JA: Changes in some blood characteristics of rabbits fed cholesterol during a single catalase or peroxidase treatment. Probl Biochim Dykhanya Klin Mater Vseskarl 2: 53, 1971

14. Pozhilankova KS, Shorokhov YA: Changes in several properties of the cell membrane of erythrocytes during nutritional hypercholesterolemia. Strukt Biosuit Prevrasc Lipidov Org Zhivton Chel, Kratk Tezisy Dokl Simp, p. 124-126, 1972

15. Butkus A, Ehrhart LA, Lewis LA, McCullagh KG: Changes in red blood cell lipid composition and osmotic fragility in dogs fed an atherogenic diet. Artery 1: 46, 1974

16. Denisyuk UI: Adaptational changes of the blood circulation in patients with coronary atherosclerosis. Urach Delo 3: 21, 1977

17. Hollander W: Biochemical pathology of atherosclerosis and relationship to hypertension. ed by Genest, Jacques, Kiow, McGraw-Hill, NY, London, 1977

18. Shohet SB: Red blood cells. in Lipid Metabolism in Mammals, ed by Snyder F, Planum Press, NY, London, p 191-205, 1977

19. Dodge JT, Mitchell C, Hollander JD: The preparation and chemical characteristics of hemoglobin-free ghosts of human red blood cells. Arch Biochem Biophys 100: 119, 1963

20. Folch J, Lees H, Sloane GH: A simple method for the isolation and purification of total lipids from animal tissues. J Biol Chem 226:497, 1957

21. Leffler $\mathrm{HH}, \mathrm{McD}$ ougald $\mathrm{GH}$ : A colorimetric method for the estimation of cholesterol. Am J Clin Path 39: 311, 1963

22. Fiske CH, Subba Row Y: The colorimetric determination of phosphorus. J Biol Chem 66 : 375,1925

23. Louwerys RR: Colorimetric determination of free fatty acids. Anal Biochem 32: 331,1969

24. Brixova E, Dzurikova V: Determination of glycogen, lipids, and proteins in hepatic needle biopsy. Clin Chem Acta 36: 543, 1972

25. Lowry $\mathrm{OH}$, Rosebrough NJ, Farr AL, Randall RJ: Protein determination using FolinCiocalteau reagent. J Biol Chem 193: 265, 1951

26. Singer SJ, Nicoloson GC: The fluid mosaic model of the structure of cell membrane. 
Science 175: 720, 1972

27. Neerhout RG: Abnormalities of erythrocytes stroma lipids in hepatic diseases. J Lab Clin Med 71: 438, 1968

28. Shohet SB; Red blood cells. in Lipid Metabolism in Mammals, ed by Snyder F, Planum Press, NY, London, Vol 1, p. 205, 1977

29. Begum N, Singh M: Red cell shape changes during atherogenesis. Biorheology (submitted)

30. Papahadjopoulos D, Cowden M, Kimelberg H: Role of cholesterol in membrane. Effect on phospholipid-protein interactions, membrane permeability and enzyme activity. Biochem Biophys Acta 330: 8, 1973

31. Begum N, Singh $M_{3}$ : Experimental atherogenesis. Analysis of physical, biochemical and histopathologic changes. Paper presented at the XI International Congress of Angiology, Prague, Chzeckoslavakia, July, 1978

32. Seed WA, Wood NB: Velocity patterns in the aorta. Cardiovasc Res 5: 319, 1971

33. Nerem RM, Seed WA: In vivo study of aortic flow disturbances. Cardiovasc Res 6: 1, 1972

34. Parker KH, Seed WA: Turbulence in the aorta. Unpublished lecturc at Euromech Colloquium 32, Imperial College, London, 1973 